九州大学学術情報リポジトリ

Kyushu University Institutional Repository

\title{
Removal of Ciprofloxacin from Aqueous Solutions by Nanoscale Zerovalent Iron-Based Materials: A Mini Review
}

Falyouna, Omar

Department of Earth System Science and Technology, Interdisciplinary Graduate School of Engineering Sciences, Kyushu University

Maamoun, Ibrahim

Department of Earth System Science and Technology, Interdisciplinary Graduate School of Engineering Sciences, Kyushu University

Bensaida, Khaoula

Department of Earth System Science and Technology, Interdisciplinary Graduate School of Engineering Sciences, Kyushu University

Sugihara, Yuji

Department of Earth System Science and Technology, Interdisciplinary Graduate School of Engineering Sciences, Kyushu University

他

https://doi.org/10.5109/4102485

出版情報: Proceedings of International Exchange and Innovation Conference on Engineering \& Sciences (IEICES). 6, pp. 179-185, 2020-10-22. Interdisciplinary Graduate School of Engineering Sciences, Kyushu University

バージョン：

権利関係 : 


\title{
Removal of Ciprofloxacin from Aqueous Solutions by Nanoscale Zerovalent Iron- Based Materials: A Mini Review
}

\author{
Omar Falyouna $^{1}$, Ibrahim Maamoun ${ }^{1}$, Khaoula Bensaida ${ }^{1}$, Yuji Sugihara ${ }^{1}$, Osama Eljamal ${ }^{1}$ \\ ${ }^{1}$ Environmental Fluid Science, Department of Earth System Science and Technology, Interdisciplinary Graduate \\ School of Engineering Sciences, Kyushu University, 6-1 Kasuga-Koen Kasuga, Fukuoka 816-8580, Japan. \\ Corresponding author email: osama-eljamal@kyudai.jp (Osama Eljamal)
}

\begin{abstract}
Ciprofloxacin is a fluoroquinolone antibiotic developed to fightback several bacterial diseases. The widespread application in human and animal medicine and the low biodegradation resulted in the persistent detection of ciprofloxacin in many water systems. The occurrence of ciprofloxacin threats human and aquatic life by motivating the development of antimicrobial resistant geneses in water. Microscale (ZVI) and nanoscale zerovalent iron (nZVI) were used to efficiently remove ciprofloxacin from aqueous solutions. The aim of this mini review to summarize: (1) the possible routes for ciprofloxacin to enter the environment, (2) the mechanism of oxidizing organic pollutants by nanoscale zerovalent iron (nZVI), (3) the ways to improve the performance of nZVI and overcome its limitations and finally (4) the available treatment systems in the literature which is developed based on NZVI to remove ciprofloxacin from aqueous environments.
\end{abstract}

Keywords: Nanoscale zerovalent iron (nZVI)-based materials; Ciprofloxacin; Antimicrobial resistant genes (AMRGs); Oxidation

\section{INTRODUCTION}

Fluoroquinolones (FQs) are one of the largest classes of antibiotics that extensively used in human and animal medicine to halt the spread of microbial infections $[1,2]$. The design of fluoroquinolones (FQs) is evolved over the years to include four generations of these antibiotics [3].

Ciprofloxacin (CIP) is one of the second-generation fluoroquinolones that capable of targeting gram-negative bacteria and some gram-positive bacteria because it includes a fluorine atom in its structure (Table 1) [3, 4]. It is widely and extensively applied to treat many microbial diseases in humans and animals because of its high antimicrobial efficiency and less side effects [5, 6]. As a result of the intensive application and low biodegradation, ciprofloxacin was one of the most frequently detected antibiotics in many aquatic systems in the environment such as rivers, lakes, drinking water and groundwater [7].

The presence of ciprofloxacin in water resources even in low concentrations ( $\mathrm{ng} / \mathrm{L}$ to $\mu \mathrm{g} / \mathrm{L}$ ) facilitates the development of antimicrobial resistant bacteria (AMRs) [5]. These types of bacteria threat human health and aquatic life because they may cause fatal infections [8].

Since the persistent detection of ciprofloxacin and other types of antibiotics in many water environments, the scientists have tried to develop several methods to remove ciprofloxacin from the aquatic systems such as adsorption [9], advanced oxidation processes (AOPs) [10], biodegradation [11], reverse osmosis (RO) [12], nanofiltration and membrane processes [13].

The application of nanomaterials in the field of water and wastewater treatment is getting a significant attention because of their superior performance over the alternative techniques as they can combine several treatment methods in one system such as adsorption and oxidation. Nanoscale zerovalent iron (nZVI) is one of the most important nanomaterials for remediating different types of contaminated waters. It exhibits high adsorption capacity, high surface area and high redox potential which makes it an ideal nanomaterial for removing a wide spectrum of pollutants namely, nitrate [14-17], phosphorus [18-20], radioactive elements [21-24], heavy metals [25-27], pesticides [28], and pharmaceuticals and personal care products (PPCPs) [29].

The aim of this mini review is to summarize the following points:

- The possible pathways for ciprofloxacin to enter the environment.

- The oxidation of organic pollutants by nZVI.

- Methods to improve the efficiency of nZVI in water and wastewater treatment.

- The application of nZVI for the removal of ciprofloxacin from aqueous solutions.

Table 1. Characteristics of Ciprofloxacin

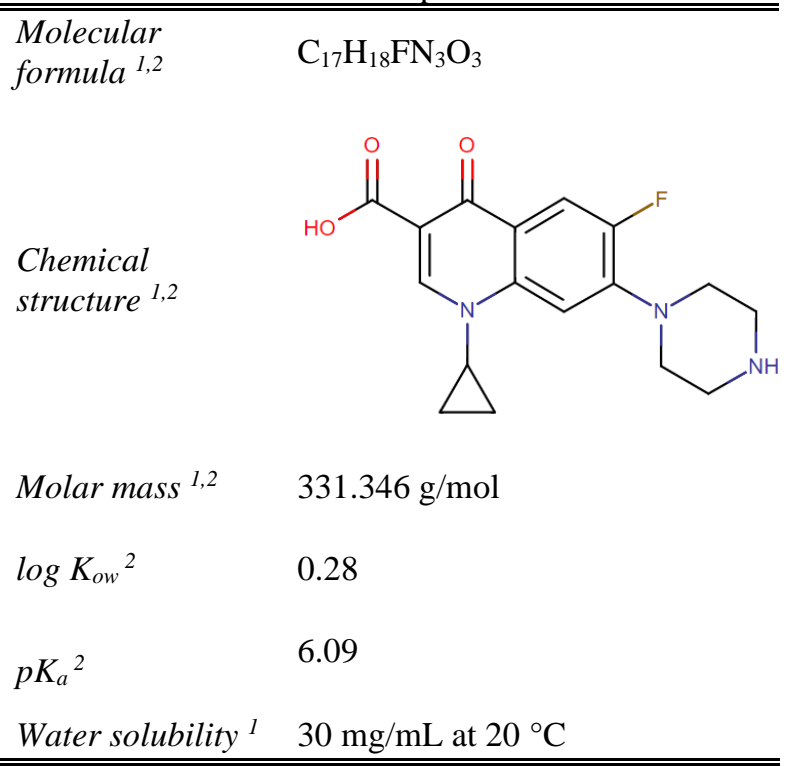

${ }^{1}$ The reference for this information is [30]

2 The reference for this information is [31] 


\section{POSSIBL ROUTES FOR CIPROFLOXACIN TO ENTER THE ENVIRONMENT}

There are several routes for ciprofloxacin to enter the environment. When ciprofloxacin is utilized in human medicine, the body will consume a small amount of it and the rest will be discharged with the feces and urine to the sewer system [31]. Eventually, the contaminated domestic wastewater with the residues of ciprofloxacin will reach the conventional wastewater treatment plants (WWTPs). Many previous researchers proved that the WWTPs are not efficient in removing the unmetabolized ciprofloxacin from the effluents of the WWTPs and ciprofloxacin residues are discharged to the surrounding surface water bodies (i.e. rivers and lakes) with the treated wastewater [32]. For example, Marcus Östman et al. studies the occurrence of antibiotics, biocides, and metals in eleven Swedish sewage treatment plants [33]. They found that ciprofloxacin was detected in all samples from the inflow wastewater (116-580 $\mathrm{ng} / \mathrm{L})$, in the treated effluents and in the sludge (1600-11000 ng/g) and in the effluents [33].

Also, the application of untreated sludge or the manure of livestock, which contain ciprofloxacin residues, in agriculture facilitates the filtration of ciprofloxacin to the groundwater. M.Boy-Roura et al. reported that ciprofloxacin and sulfamethoxazole were the most frequently detected antibiotics in the alluvial aquifer (Spain) and the surrounding surface water with $\mathrm{ng} / \mathrm{L}$ concentrations as a result of the application of manures in the agricultural practices in this area [34].

The wastewater of hospital and the antibiotic manufacturing facilities is another important way for ciprofloxacin to enter the environment with elevated concentrations that may reach the level of $\mathrm{mg} / \mathrm{L}$ [6].

\section{THE OXIDATION OF ORGANIC POLLUTANTS BY NZVI}

There are several mechanisms for nZVI to remove the contaminants from water, for instance adsorption, coprecipitation, reduction and oxidation [35].

For organic pollutants, nZVI can either adsorb them on the surface or oxidize them through the production of radicals during the reaction with oxygen (i.e. hydroxyl radicals $[\mathrm{OH} \cdot]$ or ferryl ions [Fe[IV]) [36].

When nZVI $\left(\mathrm{Fe}^{0}\right)$ reacts with oxygen the following reactions will occur depending on the $\mathrm{pH}$ of the aqueous medium $[36,37]$ :

$$
\begin{aligned}
& \mathrm{Fe}_{(s)}^{0}+\mathrm{O}_{2} \rightarrow \mathrm{H}_{2} \mathrm{O}_{2}+\mathrm{Fe}^{2+} \\
& \mathrm{Fe}_{(\mathrm{s})}^{0}+\mathrm{H}_{2} \mathrm{O}_{2} \rightarrow \mathrm{Fe}^{2+}+\mathrm{H}_{2} \mathrm{O} \\
& \mathrm{Fe}^{2+}+\mathrm{O}_{2} \rightarrow \mathrm{Fe}^{3+}+\mathrm{O}_{2}^{--} \\
& \mathrm{Fe}^{2+}+\mathrm{O}_{2}^{--} \rightarrow \mathrm{H}_{2} \mathrm{O}_{2}+\mathrm{Fe}^{3+} \\
& \mathrm{Fe}^{2+}+\mathrm{H}_{2} \mathrm{O}_{2} \rightarrow \mathrm{OH}^{2} \text { and } / \text { or } \mathrm{Fe}(\mathrm{IV}) \\
& \mathrm{Fe}^{3+} \rightarrow \mathrm{Fe}_{(\mathrm{s})}^{3+}
\end{aligned}
$$

The solid particles of nZVI $\left(\mathrm{Fe}^{0}\right)$ reacts with oxygen to produce hydrogen peroxide $\left(\mathrm{H}_{2} \mathrm{O}_{2}\right)$ and ferrous ions $\left(\mathrm{Fe}^{2+}\right)$ [reaction 1]. The highly reactive surface of $\mathrm{nZVI}$ may react again with the generated hydrogen peroxide
$\left(\mathrm{H}_{2} \mathrm{O}_{2}\right)$ to produce water and ferrous ions $\left(\mathrm{Fe}^{2+}\right)$ [reaction 2]. If reaction 2 occurs in the system, the generated $\mathrm{H}_{2} \mathrm{O}_{2}$ will be lost and converted to water rather than radicals which will decrease the oxidative capacity of nZVI. On the other hand, if the reaction cycle continues and reaction 3 and 4 occur, more hydrogen peroxide will be produced from the oxidation of ferrous ions $\left(\mathrm{Fe}^{2+}\right)$ to ferric ions $\left(\mathrm{Fe}^{3+}\right)$ by oxygen. Then, the oxidants (Hydroxyl (OH) and/or ferryl ions (Fe(IV)) will be produced through the reaction of hydrogen peroxide $\left(\mathrm{H}_{2} \mathrm{O}_{2}\right)$ and ferrous ions $\left(\mathrm{Fe}^{2+}\right)$ [reaction 5] [38]. This reaction is known as Fenton reaction [39]. Finally, the resulted oxidants inside the nZVI system will react with the organic pollutants in water to oxidize and degrade them. In reaction 6 the ferric ions will precipitate on the surface of nZVI to form iron oxide layer. This layer will negatively affect the oxidation of organic pollutants by preventing the oxidation of nZVI or by acting as a catalyst for the oxidation of ferrous ions by either oxygen or hydrogen peroxide [36, 37].

The $\mathrm{pH}$ of the medium has a strong effect on the nature of the produced radicals in the nZVI system [36, 37]. Under the acid $\mathrm{pH}$, the oxidation of nZVI [reaction $1]$ is the source of hydrogen peroxide $\left(\mathrm{H}_{2} \mathrm{O}_{2}\right)$ where the hydroxyl radicals $(\mathrm{OH})$ will be the dominant oxidants that produced in the system. However, in the neutral $\mathrm{pH}$ $(\mathrm{pH}>5), \mathrm{nZVI}$ will serve as a source for ferrous ions and the oxidation of ferrous ions [reaction 3 and 4 ] will be the responsible for generating hydrogen peroxide inside the system. It is believed that, under neutral $\mathrm{pH}$, the more selective and less reactive ferryl ions (Fe(IV)) will be generated.

\section{METHODS TO IMPROVE THE EFFICIENCY OF NZVI IN WATER AND WASTEWATER TREATMENT}

nZVI particles are highly efficient in removing large groups of organic and inorganic pollutants from water. However, there are some limiting factors hinder or adversely affect the application of nZVI in the environmental remediation of contaminated waters. For example, nZVI particles tend to agglomerate and form a chain-like structure as a result of the high surface energy [40]. Furthermore, the surface of nZVI oxidizes very fast when it is exposed to air and form a passivation layer [41] These obstacles will reduce the high specific area of nZVI and prevent the interaction between nZVI and the contaminants [41]. In addition, nZVI possess a very low oxidizing capacity towards the organic pollutants where only small fractions of nZVI will be convert to oxidants [36].

There are several approaches which researchers followed in order to tackle these pitfalls and improve the environmental performance of nZVI particles. Some of these methods are as follows:

1. Embracing nZVI particles with different supporting materials, such as zeolite [23], graphene oxide [42], activated carbon [43], biochar [44], and carbon nanotubes [45].

2. Doping the surface of nZVI with noble metals for instance, copper (Cu) [18], nickel (Ni) [46], silver (Ag) [47], gold ( $\mathrm{Au}$ ) [48], and palladium (Pd) [49], to improve the reactivity of nZVI particles. 
3. Stabilization of nZVI with different polymers and surfactants, such as polyvinylpyrrolidone (PVP) [50], carboxymethyl cellulose (CMC) [51], starch [52], guar gum [53], and polyacrylamide (PAM) [54].

4. Coating the surface of nZVI particles with thin layer of different materials such as sulfide and magnesium hydroxide $[55,56]$.

5. Addition of Fenton reagents such as hydrogen peroxide $\left(\mathrm{H}_{2} \mathrm{O}_{2}\right)$ [57] and persulfate [58].

The aim of these techniques to prevent the agglomeration of nZVI by reducing the magnetic attraction between the particles, enhance the particle's dispersion, increase the exposure of nZVI surface to react with the pollutants, increase the production of oxidants and finally improve the removal efficiency of nZVI towards many contaminants.

\section{THE APPLICATION OF NZVI FOR THE REMOVAL OF CIPROFLOXACIN FROM AQUEOUS SOLUTIONS.}

In the literature, there are 13 published articles with the focus on the application of zerovalent iron (ZVI) and nanoscale zero valent iron (nZVI), as a fundamental material, for remediating ciprofloxacin-contaminated waters. Table 2 summarizes these scientific papers with more details about the modifications that applied on ZVI and nZVI, the experimental conditions and the reported maximum removal efficiency of the proposed systems.

There is only two research groups that utilized the microscale zerovalent iron (ZVI) to remove ciprofloxacin from water. João Angelo de Lima Perini et al. applied the zero-valent iron particles (ZVI), without any modifications, to remove ciprofloxacin from aqueous medium. They found that $2.5 \mathrm{~g} / \mathrm{L}$ of ZVI was capable of removing $85 \%$ of $21.58 \mathrm{mg} / \mathrm{L}$ ciprofloxacin after 2 hours [59]. However, Nguyen Thanh Hoa et al. recorded $84.5 \%$ removal efficiency by only adding $2.25 \mathrm{mM}$ of persulfate (i.e. Fenton reagent) to strengthen the efficiency of 126 $\mathrm{mg} / \mathrm{L}$ of ZVI to remove $9.96 \mathrm{mg} / \mathrm{L}$ ciprofloxacin solution within a shorter time $(60 \mathrm{~min})$ [31]. The addition of persulfate in small quantities enhanced the production of radicals in the system which explains the huge reduction in the amount of ZVI from $2500 \mathrm{mg} / \mathrm{L}$ to $126 \mathrm{mg} / \mathrm{L}$.

The nano-sized zerovalent iron (nZVI) is more reactive and efficient than the micro-sized zerovalent iron (ZVI). This explains the tendency of researchers to apply nZVI in water treatment rather than ZVI. Eleven projects were conducted to remove ciprofloxacin from water by using nZVI as a core element in their treatment systems.

It can be seen from table 2 that all of the previous researchers reinforced nZVI with one or more of the previously mentioned techniques in section 4 to develop an efficient ciprofloxacin-removal system based on nZVI

For example, Yingying Shao et al. supported the bare nZVI with wheat straw (WS-nZVI) to overcome the aggregation problem and boost the removal of ciprofloxacin $(\mathrm{RE}=97 \%)$ [7]. Similarly, Meghdad Pirsaheb et al. [60] and Qiming Mao et al. [61] used carbon dots and biochar, respectively, as supporting materials for nZVI. Qiming Mao et al. further promoted the removal of ciprofloxacin by adding the hydrogen peroxide $\left(\mathrm{H}_{2} \mathrm{O}_{2}\right)$ (i.e. Fenton reagent) to significantly enlarge the production of radicals in the system [61]. For the same reason, Sourav Kumar Mondal et al., added the hydrogen peroxide $\left(\mathrm{H}_{2} \mathrm{O}_{2}\right)$ with a concentration of 100 $\mathrm{mM}$ to $167.54 \mathrm{mg} / \mathrm{L}$ of $\mathrm{nZVI}$ to accomplish $100 \%$ removal efficiency of ciprofloxacin after $50 \mathrm{~min}$ [10].

Meghdad Pirsaheb et al. [62] and Rahmani A.R et al. [63] combined nZVI with ultrasonication and the addition of Fenton reagents (i.e. hydrogen peroxide or persulfate) to efficiently uptake ciprofloxacin from aqueous solutions.

Jiwei Liu et al. [30] and Jie Gao et al. [64] synthesized bimetallic $\mathrm{Ni} / \mathrm{nZVI}$ and sulfide-modified $\mathrm{nZVI}$ supported by biochar (S-nZVI/BC), respectively, to effectively activate persulfate in order to produce the strong oxidants $\left(\mathrm{OH} \& \mathrm{SO}_{4}^{-{ }^{-}}\right)$that responsible for the degradation of ciprofloxacin in water.

Also, Lishuo Chen et al. stabilized the bimetallic $\mathrm{nZVI} / \mathrm{Cu}$ using the soluble polymer polyvinylpyrrolidone (PVP) where this composite was able to remove $98.4 \%$ of ciprofloxacin after $120 \mathrm{~min}$ [65]. In another research project, Lishuo Chen et al. used the green tea extracts instead of sodium borohydride to green-synthesize the bimetallic GT-nZVI/Cu nanoparticles [66]. The developed green synthesized bimetallic nanoparticles $(\mathrm{GT}-\mathrm{nZVI} / \mathrm{Cu}) \quad(\mathrm{RE}=80 \%)$ exhibited a better performance than the traditionally synthesized bimetallic nanoparticles $(\mathrm{nZVI} / \mathrm{Cu})(\mathrm{RE}=55 \%)$ in removing ciprofloxacin from aqueous solutions [66]. It is important to mention that in their both studies, Lishuo Chen et al. applied a weak magnetic field to promote the complete removal of ciprofloxacin from water $[65,66]$.

\section{CONCLUSIONS.}

Ciprofloxacin is a second-generation fluoroquinolone antibiotic that is extensively applied worldwide in human and veterinary medicine to treat several bacterial infections. Residues of ciprofloxacin were continuously detected in many water environments (ng/L to $\mu \mathrm{g} / \mathrm{L}$ ) as a result of its low biodegradability. The effluents of treatment plants which treat domestic, hospital and industrial wastewaters are the main route for ciprofloxacin to enter the environment. The persistent occurrence of ciprofloxacin in water triggers the growth of antimicrobial resistant genes. These genes can put human and aquatic life under serious danger by developing deadly diseases.

Zerovalent iron (ZVI) and nanoscale zerovalent iron (nZVI) were applied to remove and degrade ciprofloxacin in aqueous solutions. The high aggregation and passivation and low oxidative capacity limit the application of nZVI in the treatment of water and wastewater. Several techniques, such as incorporating nZVI with supporting materials, doping noble metals on the surface of nZVI, coating nZVI with polymers or reactive materials and adding Fenton reagents to the nZVI system were employed to fabricate efficient ciprofloxacin-removal systems. This mini review summarizes the developed treatment systems based on NZVI for treating ciprofloxacin-contaminated waters. 
Table 2. The utilization of nZVI or ZVI as a base material to remove ciprofloxacin from aqueous solutions.

\begin{tabular}{ccc}
\hline \hline No. & Name of the material or \\
system & Removal conditions & Removal \\
Efficiency $(\%)$ & Reference
\end{tabular}

1 Zero-valent iron $\underline{(\mathbf{Z V I})}$

Initial CIP concentration $=65 \mu \mathrm{M}$, initial $\mathrm{pH}$ $=6.5, \mathrm{ZVI}$ dosage $=2.5 \mathrm{~g} / \mathrm{L}$, contact time $=$ $85 \%$ $120 \mathrm{~min}$

2 Persulfate activated by nano zero-valent iron (nZ $\underline{\mathbf{Z V I})}$

3 Wheat straw-supported nanoscale zero-valent iron (WS-NZVI)

$4 \quad$ Nano zero-valent iron (nZVI) encapsulated in carbon dots

5 Ultrasonic enhanced zerovalent iron (nZVI)-based Fenton reaction

6 Polyvinylpyrrolidone

stabilized

NZVI/Cu bimetallic particles $\underline{\underline{\text { (PVP. }}}$ NZVI/Cu)

7 Biochar-supported nanoscale zerovalent iron $\underline{\text { (BC-nZVI) }}$ activating $\mathrm{H}_{2} \mathrm{O}_{2}$

Zero-valent metal (VI)activated persulfate oxidation

9 Persulfate activation by sulfide-modified nanoscale iron supported by biochar $\underline{(\mathbf{S}-}$ $\underline{\text { nZVI/BC) }}$

10 Green synthesized bimetallic GT-nZVI/Cu composites

11 A granular supported nanoparticle adsorbent-

$\underline{\mathrm{Fe} / \mathrm{Ni}}$ persulfate activating system

$12 \underline{\mathbf{N Z V I}} / \mathrm{H}_{2} \mathrm{O}_{2} /$ Aeration/MF

13 Modified Fenton $\left(\underline{\mathbf{n Z V I}} / \mathrm{H}_{2} \mathrm{O}_{2}\right)$
Initial CIP concentration $=50 \mathrm{mg} / \mathrm{L}$, initial $\mathrm{pH}=4.5$, PS concentration $=1200 \mathrm{mg} / \mathrm{L}$, nZVI dosage $=120 \mathrm{mg} / \mathrm{L}$, contact time $=60$ $\min$

$57 \%$

Initial CIP concentration $=50 \mathrm{mg} / \mathrm{L}$, initial $\mathrm{pH}=6$, WS-NZVI dosage $=1 \mathrm{~g} / \mathrm{L}$, contact time $=240 \mathrm{~min}$

$97 \%$

N/A

$51 \%$

Initial CIP concentration $=100 \mathrm{mg} / \mathrm{L}$, initial $\mathrm{pH}=7$, nZVI dosage $=117 \mathrm{mg} / \mathrm{L}, \mathrm{H}_{2} \mathrm{O}_{2}$ concentration $=3 \mathrm{mM}$, aeration $=1.61$ $\mathrm{L} / \mathrm{min}$, contact time $=60 \mathrm{~min}$

Initial CIP concentration $=100 \mathrm{mg} / \mathrm{L}$, initial $\mathrm{pH}=6, \mathrm{nZVI}$ dosage $=0.5 \mathrm{~g} / \mathrm{L}, \mathrm{nZVI} / \mathrm{Cu}=$ $1: 0.04$, weak magnetic field $=2 \mathrm{mT}$, reaction temperature $=35^{\circ} \mathrm{C}$, contact time $=120 \mathrm{~min}$

Initial CIP concentration $=100 \mathrm{mg} / \mathrm{L}$, initial $\mathrm{pH}=3 \sim 4$, nZVI dosage $=0.4 \mathrm{~g} / \mathrm{L}$, doses of $\mathrm{H}_{2} \mathrm{O}_{2}=20 \mathrm{mM}$, BC:nZVI = 1:1, reaction temperature $=25^{\circ} \mathrm{C}$, contact time $=60 \mathrm{~min}$

Initial CIP concentration $=30 \mu \mathrm{M}$, initial $\mathrm{pH}$ $=3, \mathrm{ZVI}$ dosage $=126 \mathrm{mg} / \mathrm{L}$, molar dosage of PS $=2.25 \mathrm{mM}$, contact time $=60 \mathrm{~min}$

Initial CIP concentration $=50 \mathrm{mg} / \mathrm{L}$, initial $\mathrm{pH}=5, \mathrm{~S}-\mathrm{nZVI} / \mathrm{BC}$ dosage $=0.4 \mathrm{~g} / \mathrm{L}, \mathrm{S} / \mathrm{Fe}$ molar ratio $=0.25$, doses of PS $=1 \mathrm{mM}$, contact time $=60 \mathrm{~min}$

Initial CIP concentration $=30 \mu \mathrm{M}$, initial $\mathrm{pH}$ $=6$, GT-nZVI $/ \mathrm{Cu}$ dosage $=0.5 \mathrm{~g} / \mathrm{L}, \mathrm{GT}-$ $\mathrm{nZVI} / \mathrm{Cu}=1 / 0.08)$, weak magnetic field $=$ $5 \mathrm{mT}$, reaction temperature $=35^{\circ} \mathrm{C}$, contact time $=90 \mathrm{~min}$

Initial CIP concentration $=100 \mathrm{mg} / \mathrm{L}$, initial $\mathrm{pH}=3.0$, PS concentration $=10 \mathrm{mM}$, $\mathrm{Ni} @$ PGA dosage $=0.1 \mathrm{~g}$, and reaction temperature $=30^{\circ} \mathrm{C}$, contact time $=12 \mathrm{~h}$.

Initial CIP concentration $=100 \mathrm{mg} / \mathrm{L}$, initial $\mathrm{pH}=7.0, \mathrm{nZVI}$ dosage $=600 \mathrm{mg} / \mathrm{L}, \mathrm{WMF}=$ $40 \mathrm{mT}$, contact time $=10 \mathrm{~min}$.

$97 \%$

Initial CIP concentration $=10 \mathrm{mg} / \mathrm{L}$, initial $\mathrm{pH}=7.0, \mathrm{nZVI}$ dosage $=167.54 \mathrm{mg} / \mathrm{L}, \mathrm{H}_{2} \mathrm{O}_{2}$ dosage $=100 \mathrm{mM}$, contact time $=50 \mathrm{~min}$. 


\section{REFERENCES}

[1] P. Sukul, M. Spiteller, Fluoroquinolone Antibiotics in the Environment, Reviews of Environmental Contamination and Toxicology, Springer New York, New York, NY, 2007, pp. 131-162.

[2] M. Yoosefian, S. Ahmadzadeh, M. Aghasi, M. Dolatabadi, Optimization of electrocoagulation process for efficient removal of ciprofloxacin antibiotic using iron electrode; kinetic and isotherm studies of adsorption, Journal of Molecular Liquids 225 (2017) 544-553.

[3] A.A. Robinson, J.B. Belden, M.J. Lydy, Toxicity of fluoroquinolone antibiotics to aquatic organisms, Environmental toxicology and chemistry 24(2) (2005) 423-30.

[4] W.-T. Jiang, P.-H. Chang, Y.-S. Wang, Y. Tsai, J.-S. Jean, Z. Li, K. Krukowski, Removal of ciprofloxacin from water by birnessite, Journal of Hazardous Materials 250251 (2013) 362-369.

[5] Y. Jia, S.K. Khanal, H. Shu, H. Zhang, G.-H. Chen, H. $\mathrm{Lu}$, Ciprofloxacin degradation in anaerobic sulfatereducing bacteria (SRB) sludge system: Mechanism and pathways, Water Res 136 (2018) 64-74.

[6] S. Ahmadzadeh, A. Asadipour, M. Pournamdari, B. Behnam, H.R. Rahimi, M. Dolatabadi, Removal of ciprofloxacin from hospital wastewater using electrocoagulation technique by aluminum electrode: Optimization and modelling through response surface methodology, Process Safety and Environmental Protection 109 (2017) 538-547.

[7] Y. Shao, P. Zhao, Q. Yue, Y. Wu, B. Gao, W.J.E. Kong, E. Safety, Preparation of wheat straw-supported Nanoscale Zero-Valent Iron and its removal performance on ciprofloxacin, 158 (2018) 100-107.

[8] H. Wang, C. Hu, L. Liu, X. Xing, Interaction of ciprofloxacin chlorination products with bacteria in drinking water distribution systems, Journal of Hazardous Materials 339 (2017) 174-181.

[9] Y. Wang, J. Lin, Y. Wang, Z. Liu, J. Lian, M. Liu, Highly efficient and selective removal of low-concentration antibiotics from aqueous solution by regenerable $\mathrm{Mg}(\mathrm{OH}) 2$, Journal of Environmental Sciences 87 (2020) 228-237.

[10] S.K. Mondal, A.K. Saha, A. Sinha, Removal of ciprofloxacin using modified advanced oxidation processes: Kinetics, pathways and process optimization, Journal of Cleaner Production 171 (2018) 1203-1214.

[11] X. Liao, B. Li, R. Zou, Y. Dai, S. Xie, B. Yuan, Biodegradation of antibiotic ciprofloxacin: pathways, influential factors, and bacterial community structure, Environmental Science and Pollution Research 23(8) (2016) 7911-7918.

[12] J.J.S. Alonso, N. El Kori, N. Melián-Martel, B. Del RíoGamero, Removal of ciprofloxacin from seawater by reverse osmosis, Journal of Environmental Management 217 (2018) 337-345.

[13] S.P. Sun, T.A. Hatton, T.-S. Chung, Hyperbranched Polyethyleneimine Induced Cross-Linking of Polyamide-imide Nanofiltration Hollow Fiber Membranes for Effective Removal of Ciprofloxacin,
Environmental Science \& Technology 45(9) (2011) 4003-4009.

[14] A.M.E. Khalil, O. Eljamal, T.W.M. Amen, Y. Sugihara, N. Matsunaga, Optimized nano-scale zero-valent iron supported on treated activated carbon for enhanced nitrate and phosphate removal from water, Chemical Engineering Journal 309 (2017) 349-365.

[15] A.M.E. Khalil, O. Eljamal, S. Jribi, N. Matsunaga, Promoting nitrate reduction kinetics by nanoscale zero valent iron in water via copper salt addition, Chemical Engineering Journal 287 (2016) 367-380.

[16] T. Shubair, O. Eljamal, A.M.E. Khalil, N. Matsunaga, Multilayer system of nanoscale zero valent iron and $\mathrm{Nano}-\mathrm{Fe} / \mathrm{Cu}$ particles for nitrate removal in porous media, Separation and Purification Technology 193 (2018) 242254.

[17] A.M.E. Khalil, O. Eljamal, B.B. Saha, N. Matsunaga, Performance of nanoscale zero-valent iron in nitrate reduction from water using a laboratory-scale continuous-flow system, Chemosphere 197 (2018) 502512.

[18] O. Eljamal, I.P. Thompson, I. Maamoun, T. Shubair, K. Eljamal, K. Lueangwattanapong, Y. Sugihara, Investigating the design parameters for a permeable reactive barrier consisting of nanoscale zero-valent iron and bimetallic iron/copper for phosphate removal, Journal of Molecular Liquids 299 (2020) 112144.

[19] S. Takami, O. Eljamal, A.M.E. Khalil, R. Eljamal, N. Matsunaga, DEVELOPMENT OF CONTINUOUS SYSTEM BASED ON NANOSCALE ZERO VALENT IRON PARTICLES FOR PHOSPHORUS REMOVAL, Journal of JSCE 7(1) (2019) 30-42.

[20] I. Maamoun, O. Eljamal, A.M.E. Khalil, Y. Sugihara, N. Matsunaga, Phosphate Removal Through Nano-ZeroValent Iron Permeable Reactive Barrier; Column Experiment and Reactive Solute Transport Modeling, Transport in Porous Media 125(2) (2018) 395-412.

[21] O. Eljamal, T. Shubair, A. Tahara, Y. Sugihara, N. Matsunaga, Iron based nanoparticles-zeolite composites for the removal of cesium from aqueous solutions, Journal of Molecular Liquids 277 (2019) 613-623.

[22] T. Shubair, O. Eljamal, A.M.E. Khalil, A. Tahara, N. Matsunaga, Novel application of nanoscale zero valent iron and bimetallic nano-Fe/Cu particles for the treatment of cesium contaminated water, Journal of Environmental Chemical Engineering 6(4) (2018) 4253-4264.

[23] O. Falyouna, O. Eljamal, I. Maamoun, A. Tahara, Y. Sugihara, Magnetic zeolite synthesis for efficient removal of cesium in a lab-scale continuous treatment system, Journal of Colloid and Interface Science 571 (2020) 66-79.

[24] O. Falyouna, Removal of Cesium from Contaminated Waters by Employing Iron-Based Nanoparticles and Nanocomposites, School of Engineering Sciences, Kyushu University, 2019.

[25] O. Eljamal, K. Sasaki, T. Hirajima, Numerical simulation for reactive solute transport of arsenic in permeable reactive barrier column including zero-valent 
iron, Applied Mathematical Modelling 35(10) (2011) 5198-5207.

[26] I. Maamoun, O. Eljamal, O. Falyouna, R. Eljamal, Y. Sugihara, Multi-objective optimization of permeable reactive barrier design for $\mathrm{Cr}(\mathrm{VI})$ removal from groundwater, Ecotoxicology and Environmental Safety 200 (2020) 110773.

[27] O. Eljamal, K. Sasaki, T. Hirajima, Sorption Kinetic of Arsenate as Water Contaminant on Zero Valent Iron \% J Journal of Water Resource and Protection, Vol.05No.06 (2013) 5 .

[28] K. Ulucan-Altuntas, E. Debik, Dechlorination of dichlorodiphenyltrichloroethane (DDT) by $\mathrm{Fe} / \mathrm{Pd}$ bimetallic nanoparticles: Comparison with nZVI, degradation mechanism, and pathways, Frontiers of Environmental Science \& Engineering 14(1) (2019) 17.

[29] A. Masud, N.G.C. Soria, D.S. Aga, N.J.E.S.W.R. Aich, Technology, Adsorption and advanced oxidation of diverse pharmaceuticals and personal care products (PPCPs) from water using highly efficient rGO-nZVI nanohybrids, (2020).

[30] J. Liu, Y. Du, W. Sun, Q. Chang, C.J.C.J.o.C.E. Peng, A granular adsorbent-supported $\mathrm{Fe} / \mathrm{Ni}$ nanoparticles activating persulfate system for simultaneous adsorption and degradation of ciprofloxacin, 28(4) (2020) 1077 1084.

[31] N.T. Hao, H. Nguyen, L. Nguyen, K.N. Do, L.D.J.J.o.W.P.E. Vu, Efficient removal of ciprofloxacin in aqueous solutions by zero-valent metal-activated persulfate oxidation: A comparative study, 35 (2020) 101199.

[32] A.L. Batt, S. Kim, D.S. Aga, Comparison of the occurrence of antibiotics in four full-scale wastewater treatment plants with varying designs and operations, Chemosphere 68(3) (2007) 428-435.

[33] M. Östman, R.H. Lindberg, J. Fick, E. Björn, M. Tysklind, Screening of biocides, metals and antibiotics in Swedish sewage sludge and wastewater, Water Res 115 (2017) 318-328.

[34] M. Boy-Roura, J. Mas-Pla, M. Petrovic, M. Gros, D. Soler, D. Brusi, A. Menció, Towards the understanding of antibiotic occurrence and transport in groundwater: Findings from the Baix Fluvià alluvial aquifer (NE Catalonia, Spain), Science of The Total Environment 612 (2018) 1387-1406.

[35] I. Maamoun, Effect of Nano Zero Valent Iron Delivery Method into Porous Media on Phosphorus Removal from Groundwater, School of Engineering Sciences, Kyushu University, 2019.

[36] C.R. Keenan, D.L. Sedlak, Ligand-Enhanced Reactive Oxidant Generation by Nanoparticulate Zero-Valent Iron and Oxygen, Environmental Science \& Technology 42(18) (2008) 6936-6941.

[37] C.R. Keenan, D.L. Sedlak, Factors Affecting the Yield of Oxidants from the Reaction of Nanoparticulate ZeroValent Iron and Oxygen, Environmental Science \& Technology 42(4) (2008) 1262-1267.

[38] E. Lefevre, N. Bossa, M.R. Wiesner, C.K.J.S.o.t.T.E. Gunsch, A review of the environmental implications of in situ remediation by nanoscale zero valent iron (nZVI): behavior, transport and impacts on microbial communities, 565 (2016) 889-901.

[39] E. Neyens, J. Baeyens, A review of classic Fenton's peroxidation as an advanced oxidation technique, Journal of Hazardous Materials 98(1) (2003) 33-50.

[40] Y. Hwang, Y.-C. Lee, P.D. Mines, Y.S. Huh, H.R. Andersen, Nanoscale zero-valent iron (nZVI) synthesis in a Mg-aminoclay solution exhibits increased stability and reactivity for reductive decontamination, Applied Catalysis B: Environmental 147 (2014) 748-755.

[41] S. Bae, R.N. Collins, T.D. Waite, K. Hanna, Advances in Surface Passivation of Nanoscale Zerovalent Iron: A Critical Review, Environmental Science \& Technology 52(21) (2018) 12010-12025.

[42] L. Ren, J. Dong, Z. Chi, H. Huang, Reduced graphene oxide-nano zero value iron (rGO-nZVI) microelectrolysis accelerating $\mathrm{Cr}(\mathrm{VI})$ removal in aquifer, Journal of Environmental Sciences 73 (2018) 96-106.

[43] C. Chang, F. Lian, L. Zhu, Simultaneous adsorption and degradation of $\gamma-\mathrm{HCH}$ by $\mathrm{nZVI} / \mathrm{Cu}$ bimetallic nanoparticles with activated carbon support, Environmental Pollution 159(10) (2011) 2507-2514.

[44] S. Wang, M. Zhao, M. Zhou, Y.C. Li, J. Wang, B. Gao, S. Sato, K. Feng, W. Yin, A.D. Igalavithana, P. Oleszczuk, X. Wang, Y.S. Ok, Biochar-supported nZVI (nZVI/BC) for contaminant removal from soil and water: A critical review, Journal of Hazardous Materials 373 (2019) 820-834.

[45] X. Lv, J. Xu, G. Jiang, X. Xu, Removal of chromium(VI) from wastewater by nanoscale zero-valent iron particles supported on multiwalled carbon nanotubes, Chemosphere 85(7) (2011) 1204-1209.

[46] R. Mokete, O. Eljamal, Y. Sugihara, Exploration of the reactivity of nanoscale zero-valent iron (NZVI) associated nanoparticles in diverse experimental conditions, Chemical Engineering and Processing Process Intensification 150 (2020) 107879.

[47] K. Bensaida, Effect of Bimetallic Zero Valent Iron Nanoparticles Ag/NZVI on Bacterial Growth, School of Engineering Sciences, Kyushu University, 2019.

[48] Y. Su, A.S. Adeleye, Y. Huang, X. Sun, C. Dai, X. Zhou, Y. Zhang, A.A. Keller, Simultaneous removal of cadmium and nitrate in aqueous media by nanoscale zerovalent iron (nZVI) and $\mathrm{Au}$ doped nZVI particles, Water Res 63 (2014) 102-111.

[49] F. He, D. Zhao, J. Liu, C.B. Roberts, Stabilization of $\mathrm{Fe}-\mathrm{Pd}$ Nanoparticles with Sodium Carboxymethyl Cellulose for Enhanced Transport and Dechlorination of Trichloroethylene in Soil and Groundwater, Industrial \& Engineering Chemistry Research 46(1) (2007) 29-34.

[50] M.A. Kumar, S. Bae, S. Han, Y. Chang, W. Lee, Reductive dechlorination of trichloroethylene by polyvinylpyrrolidone stabilized nanoscale zerovalent iron particles with $\mathrm{Ni}$, Journal of Hazardous Materials 340 (2017) 399-406.

[51] S. Zhang, H. Lyu, J. Tang, B. Song, M. Zhen, X. Liu, A novel biochar supported CMC stabilized nano zero- 
valent iron composite for hexavalent chromium removal from water, Chemosphere 217 (2019) 686-694.

[52] Y. Sun, R. Jing, F. Zheng, S. Zhang, W. Jiao, F. Wang, Evaluating phytotoxicity of bare and starch-stabilized zero-valent iron nanoparticles in mung bean, Chemosphere 236 (2019) 124336.

[53] H. Li, Y. Ge, X. Zhang, High efficient removal of lead from aqueous solution by preparation of novel PPGnZVI beads as sorbents, Colloids and Surfaces A: Physicochemical and Engineering Aspects 513 (2017) 306-314.

[54] W. Wang, S. Li, H. Lei, B. Pan, W.-x. Zhang, Enhanced separation of nanoscale zero-valent iron (nZVI) using polyacrylamide: Performance, characterization and implication, Chemical Engineering Journal 260 (2015) 616-622.

[55] I. Maamoun, O. Eljamal, R. Eljamal, O. Falyouna, Y. Sugihara, Promoting aqueous and transport characteristics of highly reactive nanoscale zero valent iron via different layered hydroxide coatings, Applied Surface Science 506 (2020) 145018.

[56] I. Maamoun, O. Eljamal, O. Falyouna, R. Eljamal, Y.J.W.S. Sugihara, Technology, Stimulating effect of magnesium hydroxide on aqueous characteristics of iron nanocomposites, 80(10) (2019) 1996-2002.

[57] M. Pirsaheb, S. Moradi, M. Shahlaei, X. Wang, N. Farhadian, Simultaneously implement of both weak magnetic field and aeration for ciprofloxacin removal by Fenton-like reaction, Journal of Environmental Management 246 (2019) 776-784.

[58] J. Wang, S. Wang, Activation of persulfate (PS) and peroxymonosulfate (PMS) and application for the degradation of emerging contaminants, Chemical Engineering Journal 334 (2018) 1502-1517.

[59] J.A. de Lima Perini, B.F. Silva, R.F.P.J.C. Nogueira, Zero-valent iron mediated degradation of ciprofloxacinassessment of adsorption, operational parameters and degradation products, 117 (2014) 345-352.

[60] M. Pirsaheb, S. Moradi, M. Shahlaei, X. Wang, N.J.J.o.C.P. Farhadian, A new composite of nano zerovalent iron encapsulated in carbon dots for oxidative removal of bio-refractory antibiotics from water, 209 (2019) 1523-1532.

[61] Q. Mao, Y. Zhou, Y. Yang, J. Zhang, L. Liang, H. Wang, S. Luo, L. Luo, P. Jeyakumar, Y.S.J.J.o.h.m. Ok, Experimental and theoretical aspects of biocharsupported nanoscale zero-valent iron activating $\mathrm{H} 2 \mathrm{O} 2$ for ciprofloxacin removal from aqueous solution, 380 (2019) 120848.

[62] M. Pirsaheb, S. Moradi, M. Shahlaei, X. Wang, N.J.E.P. Farhadian, Ultrasonic Enhanced Zero-Valent Iron-Based Fenton Reaction for Ciprofloxacin Removal under Aerobic Condition, 7(1) (2020) 227-241.

[63] A. Rahmani, H. Almasi, S. Bajalan, H. Rezaei Vahidian, A. Zarei, A.J.J.o.H. Shabanloo, Optimization of ciprofloxacin antibiotic sonochemical degradation with persulfate activated by nano zero-valent iron by central composite design method, 8(3) (2017) 231-245.
[64] J. Gao, D. Han, Y. Xu, Y. Liu, J.J.S. Shang, P. Technology, Persulfate activation by sulfide-modified nanoscale iron supported by biochar (S-nZVI/BC) for degradation of ciprofloxacin, 235 (2020) 116202.

[65] L. Chen, T. Yuan, R. Ni, Q. Yue, B.J.C.E.J. Gao, Multivariate optimization of ciprofloxacin removal by polyvinylpyrrolidone stabilized $\mathrm{NZVI/Cu}$ bimetallic particles, 365 (2019) 183-192.

[66] L. Chen, R. Ni, T. Yuan, Y. Gao, W. Kong, P. Zhang, Q. Yue, B.J.J.o.h.m. Gao, Effects of green synthesis, magnetization, and regeneration on ciprofloxacin removal by bimetallic nZVI/Cu composites and insights of degradation mechanism, 382 (2020) 121008. 